\title{
Sustainability Reporting (SR) Disclosure and Value Relevance on Listed Saudi Firms
}

\author{
Hassan Mousa Haidar, Rabia Minatullah Sohail \\ Business Department, Jeddah International College, Jeddah, Saudi Arabia \\ Email: Hassan@jicollege.edu.sa, Rabia@jicollege.edu.sa
}

How to cite this paper: Haidar, H. M., \& Sohail, R. M. (2021). Sustainability Reporting (SR) Disclosure and Value Relevance on Listed Saudi Firms. Open Journal of Business and Management, 9, 1782-1804. https://doi.org/10.4236/ojbm.2021.94097

Received: June 16, 2021

Accepted: July 16, 2021

Published: July 19, 2021

Copyright (อ 2021 by author(s) and Scientific Research Publishing Inc. This work is licensed under the Creative Commons Attribution International License (CC BY 4.0).

http://creativecommons.org/licenses/by/4.0/

\begin{abstract}
This study examines whether Sustainability Reporting (SR) contributes to the financial performance indicators of Saudi listed firms. The study's data are imperiled to regression analysis using the econometric model in computing the Tobin's $Q$ value as proposed under the section on study variables. It also examines the value significance of SR on financial performance among the listed firms in Tadawul by determining whether Tobin's $Q$ is statistically significant by specific firm's attributes, including firm size, leverage, and EPS. The outcomes indicate that Tobin's $Q$ is statistically significantly influenced by leverage, EPS and firm size. Additionally, the study validates that no correlation occurs between the SR practices of the listed firms in Tadawul and the corporate financial performance.
\end{abstract}

\section{Keywords}

Sustainability, Sustainability Reporting, Tobin-Q, Global Reporting Initiatives(GRI), Islamic Reporting Initiatives (IRI)

\section{Introduction}

In the past years, the business domain has increasingly focused on sustainability reporting or SR (Dixon-Fowler et al., 2013; Tvaronavičiene et al., 2017). SR is a voluntary or mandatory reporting by organizations or firms on the social, economic/financial and environmental impacts arising from their operations or activities on a daily basis. Literature on SR shows that firms that adopt SR practices pursue organizational legitimacy (Hedberg \& Malmborg, 2003), yield to the need to consider the board's oversight (Carroll \& Shabana, 2010; Dyllick \& Hockerts, 2002), pursue ethics, compliance and external accreditation (Gray et al., 2014; Kolk, 2004) as well as report achievements and stakeholder issues through active engagement of stakeholders (Mulkhan, 2013). From the perspective of 
stock prices, Ansari, Cajias, and Bienert (2015) and Gray et al. (2014) established that SR positively affected stock prices of real estate organizations. Other studies have shown diverse findings, including the value of SR to stakeholders and the reporting entity (Loh, Thomas, \& Wang, 2017; Lourenço et al., 2014). SR is more useful for internal communication than external (Farneti \& Guthrie, 2009; Hedberg \& Malmborg, 2003). It offers more qualitative than quantitative information on financial value. Other empirical studies agree or disagree less on the usefulness of SR practices (Gray et al., 2014; Gray \& Milne, 2002).

From the perspective of shareholders, the usefulness of SR information is measured by the relevance of the value of the filed information in making investment decisions (Dyllick \& Hockerts, 2002; Hyršlová et al., 2015; Lourenço et al., 2014). Studies have explored the correlation between SR and financial performance and confirmed the impact of SR information on investment decisions by shareholders by considering variables, such as book value and share earnings (Gray, Adams, \& Owen, 2014; Owen, 2007). Therefore, the current study explores SR or disclosure and value relevance on listed Saudi firms. In particular, the study determines whether SR practices by listed Saudi firms creates higher value relevance on financial performance based on financial statements as compared to firms that do not engage in SR or disclosure.

Wang (2015) makes an observation indicating that scholars are adopting the concept of firm value in quest for demonstrating the firm's intangible intellectual capital and the conventional financial capital. In this context, researchers have invented the use of Tobin's $Q$ score for valuation purposes. In the quest for assessing firm's value, scholars have gone to the length of considering corporate governance. Informed by these theoretical studies can be conducted to examine the correlation between the Tobin's $\mathrm{Q}$ score and the corporate governance performance variables. On this basis, a multi-regression model was adopted in presenting the analysis and discussion pertaining to value relevance of corporate governance and intellectual capital. The analysis demonstrates that corporate governance performance yields positive influence on the correlation between firm valuation and intellectual capital.

More importantly, this study makes three main contributions to the literature on sustainability reporting in the following ways. Firstly, the study contributes to the existing literature on the value relevance of sustainability reports during investment decision-making among shareholders. This is realized by demonstrating how SR practices yields value relevance on listed forms, inevitably demonstrating how shareholders benefits from value relevance reporting through SR practices when making investment decisions. Secondly, the study contributes to the existing accounting research on SR by obtaining the empirical evidence on value relevance of SR information among listed firms. The findings would add to the current literature on significance of SR practices by listed firms by demonstrating whether firms undertaking SR practices have higher value relevance as evidenced by specific financial performance indicators compared to companies 
that do not. Thirdly, the study contributes significantly to the existing debate on SR framework and the external assurance on value relevance of listed firms. In this context, the study makes invaluable theoretical addition to the importance and value relevance of publicizing social and environmental information by listed entities.

The rest of the study is presented in five sections. Section 2 presents the theoretical framework of the current study by looking at pertinent theories that explains the concept of SR and value relevance. In this section, the research builds on two theories, namely stakeholder theory and legitimacy theories. A detailed analysis is presented, and a selection of the most appropriate is justified based on past evidence. Section 3 presents literature review and hypothesis development by documenting past studies in examining the relationship between SR and value relevance. Similarly, the section presents the key findings (development) to evidence the correlation between SR and value relevance, as well as the study approach and methodology. Section 4 presents the study findings and discussion. Section 5 presents discussions on the findings followed by conclusions, and finally the study limitations and commentary on future studies.

\section{Theoretical Framework}

Stakeholder and legitimacy theories are among the most relevant theories on SR and value relevance (Belal, 2003; Mashat, 2005). The theories are developed from an institutional school of thought that categorizes stakeholder and legitimacy theories based on political-economy theory. This category of theories does not consider the viewpoint that firms have material or technological incentives, but rather assumes the perspective that an organization's rituals, cultural norms, beliefs and symbols influences its behavior (Hahn \& Kühnen, 2013; Suchman, 1995). The legitimacy theory assumes that firms persistently engage in perceived legitimacy by ensuring their operations or activities remain within a constructed system of definitions, beliefs, values, norms and bounds of the society (Deegan, 2009; Hedberg \& Malmborg, 2003). As observed by Dowling and Pfeffer (1975) and Mobus (2005), SR and CSR practices act as a mode of communication aimed at convincing the society that the organization's activities are compliant with the existing "social contract" or societal norms and bounds that govern organizations' behavior. In this background, any change in societal expectations would lead to the need for a firm to change and adapt as well.

According to Golob and Bartlett (2007) and Suchman (1995), organisations would act differently in response to the changes based on whether the firm gains, repairs or aims at maintaining legitimacy. Hence, the firm uses SR or CSR disclosure as a tool for legitimizing its activities or undertakings by offering information that influence the society and stakeholders' perception about the organization (Golob \& Bartlett, 2007; Hooghiemstra, 2000). In agreement, Boesso and Kummar (2007) and Hassanein and Hussainey (2015) confirmed that the re- 
porting organization may provide social and environmental information using the annual reports to enhance the organizations' reputation among stakeholders, as well as to satisfy the society's need. More importantly, there would be a legitimacy gap should the organization breach the social contract. Therefore, organizations adopt CSR or SR to close the inevitable legitimacy gap. In doing so, the organization may opt to communicate to the public or external stakeholders about their actual SR or CSR policies in changing the company's reputation through emotive symbols that divert public attention on other important, related issues or by altering societal expectations (Hassanein \& Hussainey, 2015; O'Donovan, 2002). Conversely, stakeholder theory considers the organization as an integral element of the broader system whereby the organization is not only affected by but also affects other stakeholder groups (Bebbington, 2001; Smith, Haniffa, \& Fairbrass 2011). Unlike the legitimacy theory that seeks conformity with societal contracts and norms, stakeholder theory is fundamentally driven by the need for accountability to the firm's stakeholders by providing an account of the activities for which the firm is solely responsible (Freeman, 1984; Cooper \& Owen, 2007; Deegan, 2002). Importantly, stakeholder theory is supported by two ideologies first, the ethical branch that takes on a normative viewpoint contending that all firm's stakeholders ought to be treated equally. For sustainability disclosure, this translates to the duty of providing all stakeholders with any relevant information as reserves equal rights in receiving this information. Therefore, any argument on whether communication would yield improved financial results or not is irrelevant (Bebbington, 2001; Cooper \& Owen, 2007; Deegan, 2002; Smith et al., 2011).

The second ideology is the managerial branch that espouses a stakeholder in availing information on the organization with resources determines the management's intention to invest more in managing the stakeholder relationship (Deegan, 2002; Phillips, 2003). In the context of SR or CSR disclosure, a few researchers conclude, based on the importance of the stakeholder to the firm, that the management would seek to disclose relevant information in seeking support from the stakeholders as well as in helping to manage diverging conflicts of interests (Bebbington, 2001; Mainardes, Alves, \& Raposo, 2011; Sun et al., 2010). Casey and Grenier (2015) and Gray, Kouhy and Lavers (1995) assert that SR is an effective method to ensure support of the stakeholder groups, resulting in guaranteed firm survival. When a company faces extreme pressure from stakeholders, SR would help in building stakeholders' confidence level when the resulting sustainability reports have been fully endorsed by a recognized assurance body (KPMG, 2008, 2013).

In effect, Gray, Owen and Adams (1996) and Smith et al. (2011) indicate that the legitimacy theory provides a seemingly superior explanation to voluntary sustainability disclosure. The major limitation of legitimacy theory involves its basis on an invalidated assumption that all organizations would seek to legitimize their operations by voluntarily disclosing their social and environmental 
performance in conjunction with the financial dimensions, yet establishing congruence between desirable actions and a socially constructed system characterized by beliefs, norms, definitions and values is realistically impossible in the globalized world (Deegan, 2000; Gray et al., 1995). However, as observed by Deegan (2002) and Gray et al. (1996), legitimacy theory is most often used by organizations in democratic or developed countries, while the stakeholder theory suits organizations operating in authoritarian or developing countries where the organizations can effectively manage the interests of its stakeholders without a negative spill-over.

Therefore, the present study focuses on Saudi Arabia as it is a developing country mainly governed by Islamic norms and value constraints. Hence, the stakeholder theory would be a relevant theoretical framework to inform the SR and value relevance in listed firms. As justified by several researchers, stakeholder theory is better suited because of its descriptive accuracy, normative validity and instrumental power, and thus it's feasible in real organizational settings or the real world, as it pursues managerial influence or manipulation in seeking stakeholders' approval and support (Donaldson \& Preston, 1995; Deegan, 2000; Gray et al., 1996; Mitchell, Agle, \& Wood, 1997).

\section{Literature Review and Hypothesis Development}

\subsection{Sustainability Reporting (SR) and Value Relevance}

Several past studies have examined the correlation between SR and value relevance of accounting information to external and internal stakeholders or users. Ansari et al. (2015) and Przychodzen and Przychodzen (2013) adopted an event study methodology on a global sample of firms in Australia, the United States and Europe and established that SR has a positive effect on the stock prices of select real estate firms. The outcome revealed that SR and the communications with stakeholders on social, financial/economic and environment performance had an impact on a firm's valuation, thus significantly influencing shareholders' decision making (Ansari et al., 2015; Simnet, Vanstraelen, \& Chua, 2009). The findings are consistent with the notion of an existing trend of positive support towards an organization's efforts (Chwistecka-Dudek, 2016; Oláh et al., 2017). In contrast, Gray and Milne (2002) contradict the influence of SR practices on value relevance of the financial information captured for users' interests. Other studies (Graham \& King, 2000; Loh et al., 2017; Lourenço et al., 2014) have evidenced the positive relationship between SR practices of a company and value relevance of the information on financial performance.

Anandarajan et al. (2011) and Mohan and John (2011) established a positive correlation between a firm's SR practices and value relevance of the resulting financial information using earnings per share (EPS), book value per share and change in EPS. Other studies concurred that contextual factors, such as investor protection through mandatory SR practices, adoptions of GRI 3.1 on SR and improvements in the firm's working capital efficiency, had a positive influence 
on the value relevance of the final fiscal information used by shareholders in making investment decisions (Anandarajan et al., 2011; Graham \& King, 2000; Wang, 2015). From a divergent perspective, Ching et al. (2017) and Chwistecka-Dudek (2016) studied the association between SR and value relevance by considering the financial performance and concluded that there is no positive correlation between value relevance of listed firms and SR practices. In this background, it can be inferred that increasing the inherent quality of SR practices does not necessarily improve the value relevance and financial performance (Ansari et al., 2015).

In contrast to these earlier findings, Loh et al. (2017) and Lourenço et al. (2014) examined the correlation between SR and firm value and established that organisations with SR procedures or framework tend to register higher firm values than those that never present their sustainability reports. In particular, Lourenço et al. (2014) and Surroca, Tribó and Waddock (2010) studied the association between SR and selected value relevance financial metrics, such as net operating income and book value of stock, and found a positive association between the variables, with firms that adopted SR practices reporting higher relevance value relating to net operating income and book value of stocks. Nonetheless, Gray and Milne (2002) and Wang (2015) believed that the value relevance on financial performance cannot be exclusively associated with SR practices because, in reality, SR is difficult or even impossible without adopting reporting guidelines, such as GRI. In agreement with these studies, Farneti and Guthrie (2009) and Hedberg and Malmborg (2003), in a descriptive study, confirmed the role of SR in creating value relevance for firms in terms of metrics, such as EPS, leverage and book value, in accordance with the GRI Guidelines and based on firm size and availability of governance committee.

These outcomes indicate that firms that adopted SR practices focused more on communicating qualitative information on the financial value associated with governance, social and environmental impacts rather than communicating quantitative information on value relevance with regard to book value, EPS and leverage metrics. Therefore, it is impossible to ascertain the value relevance of SR practices by the listed firms. Nonetheless, Dobre, Stanila and Brad (2015) and Truant, Corazza and Scagnelli (2017) examined the impact of SR practices by Italian and Romanian listed firms and established that these firms reported a positive long-term financial performance.

In the study by Hassel, Nilsson and Nyquist (2005) and Truant et al. (2017) on the correlation between CSR or SR practices and the market values of the listed firms, the value relevance of the annual financial reports showed great improvement by including information on social and environmental performance. The study arrived at the conclusion based on the Ohlson (1995) model to regress market values of environmental, book value and earnings performance. Despite the negative correlation between environmental performance and market values, in endorsement of the cost perspective on SR, the results confirmed that the value relevance of the financial information was significantly improved by includ- 
ing social and environmental performance information.

Other study outcomes demonstrate that SR practices of listed companies tend to have a positive impact on value relevance of diverse market performance indicators, including book value, earnings, market value, firm's returns, in firm's market value and share prices (Cardamone, Carnevale, \& Giunta, 2012; Carnevale, Mazzuca, \& Venturini, 2012; Cormier \& Magnan, 2007; de Klerk \& de Villiers, 2012; Murray et al., 2006; Schadewitz \& Niskala, 2010). These empirical studies established a correlation between full sustainability and CSR disclosure, mainly voluntary reporting, as either stand-alone reports or combined reporting alongside the financial reports. However, other studies reported contradicting outcomes, including the negative correlation between CSR disclosures or SR and firm's market value (Cardamone et al., 2012; Hassel et al., 2005; Murray et al., 2006), and a negative or no impact of SR and CSR on share prices and market value, with mandatory financial disclosure yielding more value relevance than voluntary CSR or SR practices (Carnevale et al., 2012; Moneva, Archel, \& Correa, 2006).

\subsection{Development (Key Findings)}

The outcomes from the reviewed literature are unclear. Some authors found no negative correlation between the CSR disclosures or SR and firm's market value (Cardamone et al., 2012; Hassel et al., 2005; Murray et al., 2006). In contrast, some found empirical evidence for some contradicting correlation (de Klerk \& de Villiers, 2012; Cormier \& Magnan, 2007; Schadewitz \& Niskala, 2010) and de Klerk and de Villiers (2012) and Schadewitz and Niskala (2010) arrived at identical conclusions, as the studies adopted similar methods and explored GRI compliers. However, Moneva and Cuella (2009) and Wang (2015) found mixed evidence, which established that financial environmental disclosure had a negative impact on the share prices, while SR or CSR disclosure had no impact. It was equally established that mandatory disclosure results in a positive correlation between SR or CSR disclosure and market value.

In addition, when examining the relationship between SR or CSR disclosure and the value relevance of book value and earnings, Cardamone et al. (2012), Carnevale et al. (2012), established mixed outcomes. Carnevale et al. (2012) and Truant et al. (2017) found no evidence for a positive relationship between SR or CSR disclosure and value relevance of book value and earnings. While Cardamone et al. (2012) and Deegan (2009) found a positive correlation between SR and value relevance of book value and earnings. In general, the contradicting study outcomes have shown that financial reporting tends to have higher value relevance than voluntary and mandatory SR or CSR, hence indicating no impact or a negative relationship between a firm's SR practices on specific performance metrics, such as firm's market value, share prices and earnings. A review of the extant literature on SR and value relevance reveals ambiguous results on whether SR practices have a direct impact on relevance value indicators used by share- 
holders during investment decision-making.

Under a theoretical framework, Hooghiemstra (2000), and Deegan (2009) confirmed that organizations use legitimacy theory during SR as a communication tool for legitimizing their activities by offering information that affects the society and stakeholders' perception about the organization. As established by Boesso and Kummar (2007), Mobus (2005) and O'Donovan (2002), organizations seek to close the arising legitimacy gap by providing nonfinancial information based on the annual reports to enhance the organizations' reputation, improve popularity among stakeholders and satisfy the society's need. In contrast, some authors established that stakeholder theory is based on a firm's obligation to all stakeholders by explicitly informing about its activities to users of the firm's nonfinancial and financial/economic information (Bebbington, 2001; Cooper \& Owen, 2007; Deegan, 2002; Freeman, 1984; Smith et al., 2011).

Finally, the managerial branch ideology of stakeholder theory appears far superior to the ethical branch (Bebbington, 2001; Mainardes et al., 2011; Sun et al., 2010). The managerial ideology of stakeholder theory claims that the firm's management adopts SR or CSR disclosure practice as a tool to attract stakeholder approval and their support through resources. Moreover, the present study focuses on a developing country that is highly premised on Islamic value systems, and therefore makes it reasonable to adopt stakeholder theory in exploring the SR and value relevance of Saudi listed firms. The use of stakeholder theory is justified by Donaldson and Preston (1995), Deegan (2000), Gray et al. (1996) and Mitchell et al. (1997), who concluded that stakeholder theory is superior to legitimacy theory because of the theory's descriptive accuracy, normative validity and instrumental power.

\subsection{Methodology}

The study adopts quantitative methods in ascertaining the correlation between SR and value relevance of Tadawul listed firms. Specifically, The regression analysis and ANOVA analysis yields results for proving or annulling the hypothesis based on $P$-value analysis and $t$-value analysis. In this context, the study will test the following hypotheses:

Hypothesis 1: There is a positive relationship between SR and Tobin-Q for listed firms on the Saudi Arabian Stock Exchange

Hypothesis 2: There is a positive relationship between GRI and Tobin-Q for listed firms on the Saudi Arabian Stock Exchange

Hypothesis 3: There is a positive relationship between environmental sensitivity (ES) and Tobin-Q for listed firms on the Saudi Arabian Stock Exchange

As discussed in Section 2, the correlation between SR and value relevance has been ascertained using financial performance indicators as the dependent values and the independent variables that mainly comprises of SR standards and CSR governance structures. In the analysis, the SR practices of the firm are 
usually treated as dummy variable for purposes of moderating. The availability of these variables in the current study makes it possible to test the mentioned hypotheses. More importantly, the study uses Tobin's Q score to ascertain the correlation between dependent variables (leverage, EPS, and firm size) and the independent variables (GRI reporting, SR status, governance score, size of the audit committee, and environmental sensitivity). The positive relationship demonstrates the link between SR and value relevance of listed firms, while the lack of relationship demonstrates the lack of statistical correlation between the tested variable.

\subsection{Data and Sample}

The study data were obtained from the GRI database, Bloomberg financial reports, annual reports of listed firms and firm's websites. The following statistical techniques were used to analyze the data gathered on the variables under this research: $t$-test, $P$-value, and Regression analysis.

The data were analyzed using SPSS version 24 . The relevant data related to the firm's performance and value indicators included leverage, EPS and firm size by assets base. Other important data relate to SR practices and compliance, including environmental sensitivity, SR status and GRI reporting. In total, 519 Tadawul listed firms were sampled. On using the selection criteria based on the data relevancy, it was found that 494 firms (95.2\%) did not disclose sustainability reports, while only 25 (4.8\%) were SR compliant.

The data for this econometric study are drawn from listed firms in Saudi stock exchange, Tadawul, from 2015 to 2017 fiscal period. The study considered listed firms from diverse sectors, including real estate, energy, financial services, construction materials, conglomerates, food and beverages products and aviation.

\subsection{Explanation of Variables}

The study utilizes Tobin's $\mathrm{Q}$ as the dependent variable, while the independent variables include leverage, EPS and firm size and GRI reporting, SR status, governance score, size of the audit committee and environmental sensitivity. The proposed econometrics model used to highlight the impact of SR and value relevance is as follows:

$$
\begin{aligned}
\mathrm{TQ}_{i t}= & \alpha_{i}+\beta_{1} \mathrm{SR}_{i t}+\beta_{2} \mathrm{GRI}_{i t}+\beta_{3} \mathrm{FS}_{i t}+\beta_{4} \mathrm{ES}_{i t}+\beta_{5} \mathrm{EPS}_{i t} \\
& +\beta_{6} \mathrm{~L}_{i t}+\beta_{7} \mathrm{GS}_{i t}+\beta_{8} \mathrm{~A}_{i t}+\varepsilon_{i t}
\end{aligned}
$$

Tobin's Q (dependent variable) is taken as an accounting variable that represents the value added by the firm's management. Thus, it is highly relevant to the performance variable in terms of firm's appraisal (Garg, 2015). The equation for Tobin's $\mathrm{Q}$ is as follows: (Table 1)

$$
\text { Tobin's } \mathrm{Q}=\frac{\text { Total market value of the firm }}{\text { Total asset value of the firm }}
$$


Table 1. Variable definitions.

\begin{tabular}{|c|c|c|}
\hline & Variables definitions & Expected relationship \\
\hline \multirow[b]{2}{*}{ TBN } & Dependent variable & \\
\hline & $\begin{array}{l}\text { Tobin Q defined as score obtained as the } \\
\text { ratio relationship between the firms' market } \\
\text { value and firm's total asset value. }\end{array}$ & \\
\hline & Independent variables & \\
\hline SR & $\begin{array}{l}\text { Sustainability report, defined as firm's } \\
\text { reports that provides information about social, } \\
\text { economic/financial, and environmental } \\
\text { performance (Junior, Cotter, \& Best, 2014; } \\
\text { Sherman, 2009). }\end{array}$ & $\begin{array}{l}\text { Positive relationship } \\
\text { (Ansari et al., 2015; } \\
\text { Ching et al., 2017; Dobre et al., 2015; } \\
\text { Wang, 2015). }\end{array}$ \\
\hline GRI & $\begin{array}{l}\text { GRI defined as international independent } \\
\text { standards (IIS) organization that helps firms, } \\
\text { businesses and governments report and } \\
\text { understand their impacts from social, } \\
\text { economic/financial, and environmental } \\
\text { performance (Isaksson \& Steimle, 2009; } \\
\text { Sherman, 2009; Simmons, Crittenden, } \\
\text { \& Schlegelmilch, 2018). }\end{array}$ & $\begin{array}{l}\text { Positive relationship } \\
\text { (Mulkhan, 2013; Loh et al., 2017; } \\
\text { Lourenço et al., 2014). }\end{array}$ \\
\hline FS & $\begin{array}{l}\text { FS defined as the company's size in relation } \\
\text { to its asset value within the specific industry } \\
\text { (Choi \& Dow, 2008; Mowen, Hansen, } \\
\text { \& Heitger, 2015; Said et al., 2017). }\end{array}$ & $\begin{array}{l}\text { Positive relationship } \\
\text { (Cardamone et al., 2012; } \\
\text { Carnevale et al., 2012; } \\
\text { Cormier \& Magnan, 2007; } \\
\text { Schadewitz \& Niskala, 2010). }\end{array}$ \\
\hline ES & $\begin{array}{l}\text { ES defined as the degree to which a firm is } \\
\text { responsive to the ecological or environmental } \\
\text { needs through sustainable activities } \\
\text { (Lin, Chang, \& Dang, 2015; Osarto et al., 2015). }\end{array}$ & $\begin{array}{l}\text { Positive relationship } \\
\text { (Cardamone et al., 2012; } \\
\text { Hassel et al., 2005; } \\
\text { Murray et al., 2006; Shah et al., 2016). }\end{array}$ \\
\hline $\mathrm{L}$ & $\begin{array}{l}\text { L defines as the firm's leverage in reference } \\
\text { to use of debt/borrowing in funding } \\
\text { operations (Choi \& Dow, 2008; } \\
\text { Said et al., 2017). }\end{array}$ & $\begin{array}{l}\text { Negative relationship } \\
\text { (de Klerk \& de Villiers, 2012; } \\
\text { Cormier \& Magnan, 2007; } \\
\text { Omran \& El-Galfy, 2014). }\end{array}$ \\
\hline GS & $\begin{array}{l}\text { GS defined as score indicator on firm's } \\
\text { governance risk compared with the region or } \\
\text { industry index on quality score on corporate } \\
\text { governance (Klassen, \& McLaughlin, 1996; } \\
\text { Lin et al., 2015; Lober, 1996). }\end{array}$ & $\begin{array}{l}\text { Positive relationship } \\
\text { (Bhatia \& Tuli, 2018; } \\
\text { de Klerk \& de Villiers, 2012; } \\
\text { Laskar \& Maji, 2018). }\end{array}$ \\
\hline A & $\begin{array}{l}\text { A defined as size of audit committee in } \\
\text { references to number of committee } \\
\text { members, and SR experts } \\
\text { (Mowen et al., 2015; Said et al., 2017). }\end{array}$ & $\begin{array}{l}\text { Negative relationship } \\
\text { (Mouselli \& Hussainey, 2014; } \\
\text { Nelson \& Devi, 2013; Yammeesri \& } \\
\text { Herath, 2010). }\end{array}$ \\
\hline EPS & $\begin{array}{l}\text { EPS defined as the firm's earnings per share } \\
\text { in reference earnings allocation on } \\
\text { outstanding stock from firm's profit } \\
\text { (Choi \& Dow, 2008). }\end{array}$ & $\begin{array}{l}\text { Positive relationship (Cardamone } \\
\text { et al., 2012; Carnevale et al., 2012; } \\
\text { Cormier \& Magnan, 2007; } \\
\text { Schadewitz \& Niskala, 2010). }\end{array}$ \\
\hline
\end{tabular}

$\mathrm{GRI}_{\mathrm{it}}$ is coded as $0 / 1(0=$ not disclosing the SR, $1=$ Disclosing the SR $) ; \mathrm{FS}_{\mathrm{it}}$ is the firm's size represented by total assets of the firm. $\mathrm{ES}_{\mathrm{it}}$ is environmental sensitivity Branco and Rodrigues (2008) identified environmentally sensitive industries compris ing mining, oil and gas, chemicals, construction and building ma- 
terials, forestry and paper, steel and other metals, electricity, gas distribution and water. EPS is the earnings per share, which is computed as net income divided by the weighted average number of shares $\mathrm{L}_{\mathrm{it}}$ is the leverage (average assets divided by average equity); $\mathrm{GS}_{\mathrm{it}}$ is the governance score; $\mathrm{A}_{\mathrm{it}}$ is the size of the audit committee.

\section{Results and Discussion}

\subsection{Descriptive Statistics}

Table 2 presents the descriptive statistics on the entire study sample (519 firms). The data show that the lowest value at 0.086 for 519 firms from 2015 to 2017 . However, the maximum value is nearly 10 for AIG insurance firm. The average mean for all values is 1.4 , indicating that the firm's stock is more expensive than the replacement cost of its assets and implying that the stock is overvalued. In addition, the average EPS are 1.13, which reflects the portion of a firm's profit that is allocated to each outstanding share of its common stock. A higher value is desirable because it signifies improved performance. Furthermore, Table 2 indicates different firm sizes using the total value of assets. The lowest value is 19.10 (Saudi industrial export firm) and the highest asset value is 448,642 (National Commercial Bank). Lastly, a firm's leverage is calculated by dividing average assets by average equity. This value reflects the amount of capital flowing in the form of debt; it helps in assessing the company's ability to meet its financial obligations. The average leverage ratios for the 519 firms listed in Tadawul is 25.17 .

\subsection{Correlation Matrix}

Table 3 illustrates the correlation between Tobin's Q and the independent variables. The Sig. (2-Tailed) value is less than 0.05 for all independent variables. Therefore, there is a statistically significant correlation between Tobin's $Q$ and all other independent variables (Lehmann, 1993).

\subsection{Model Summary}

Table 4 presents the summary of the regression model. It comprises the $\mathrm{R}$-Square and the adjusted $t$-square values and the resulting Durbin-Watson value. The R-square value indicates the total variation in the dependent variable

Table 2. Descriptive statistics.

\begin{tabular}{ccccccc}
\hline & N & Range & Min. & Max. & Mean & Std. Dev. \\
\hline TBN & 519 & 9.926 & 0.086 & 10.01 & 1.41 & 1.17 \\
FS & 519 & $448,622.90$ & 19.10 & 448,642 & $21,867.9$ & $65,439.5$ \\
EPS & 519 & 43.83 & -34.4 & 9.35 & 1.1334 & 2.93 \\
L & 519 & 24.99 & 0.18 & 25.17 & 2.32 & 2.24 \\
\hline
\end{tabular}


Table 3. Correlations.

\begin{tabular}{ccccccccccc}
\hline & & TBN & SR & GRI & FS & ES & EPS & L & GS & A \\
\hline \multirow{2}{*}{ TBN } & PC & 1 & -0.20 & -0.20 & -0.28 & -0.23 & 0.12 & -0.32 & -0.22 & -0.10 \\
& Sig. & & 0.00 & 0.00 & 0.00 & 0.00 & 0.01 & 0.00 & 0.03 & 0.03 \\
\hline
\end{tabular}

PC $=$ Pearson correlation, Significant level at 5\%.

Table 4. Model summary.

\begin{tabular}{ccccc}
\hline $\mathrm{R}$ & $\mathrm{R}-\mathrm{Square}$ & Adjusted R-Square & Std. Error of the Estimate & Durbin-Watson \\
\hline 0.85 & 0.726 & 0.70 & 0.34 & 1.96 \\
\hline
\end{tabular}

(Tobin's Q) that can be explained by the independent variables (Magee, 1990). In the present study, $72.6 \%$ of the variation in the dependent variable can be explained by the very large independent variables, indicating that the model is strong. Bluman (2018) specifies that the Durbin-Watson value varies between 0 and 4 . If the value is close to 2 , then there is no autocorrelation; however, a value closer to 0 indicates positive autocorrelation and a value close to 4 signifies a negative autocorrelation. In this case, the value is 1.952 , which is closer to 2 , indicating that there is no autocorrelation over the selected period.

\subsection{ANOVA Analysis}

Prediction of the Tobin's Q variable using the regression model is shown in Table 5. The statistical significance of the regression model is indicated by the ANOVA analysis (Bluman, 2018). As shown, the $p$-value is less than 0.05 , signifying that, overall, the regression model statistically and significantly predicts the outcome variable. In other words, it is a good fit for the Tadawul data.

\subsection{Regression Analysis}

Table 6 summarizes the outcomes of the regression analysis model using coefficients. In summary, the regression equation is as follows:

$$
\begin{aligned}
\mathrm{TBN}= & 2.649-0.027(\mathrm{SR})+0.029(\mathrm{GRI})-0.372(\mathrm{FS})-0.169(\mathrm{ES}) \\
& +0.138(\mathrm{EPS})-0.124(\mathrm{~L})-0.002(\mathrm{GS})+0.048(\mathrm{~A})
\end{aligned}
$$

\subsubsection{Regression Results}

The coefficient for SR is 0.027 . The SR is coded as $0 / 1(0=$ not disclosing, $1=$ disclosing). Therefore, it can be concluded that for a firm that adopts SR practices, the predicted Tobin's $Q$ would be 0.027 points lower than for a firm that does disclose sustainability reports. The coefficient for GRI is 0.029 . GRI is coded $0 / 1 / 2 / 3 / 4(0=$ No SR, $1=$ full GRI report, $2=$ GRI referenced, $3=$ Citing GRI, 4 = Non-GRI report). Thus, for every unit increase in GRI, a 0.029 unit increase in Tobin's $\mathrm{Q}$ is predicted, holding all other variables constant. For a full GRI report, the Tobin's Q score would be 0.029 points higher than for a firm that does not disclose SR status. 
Table 5. ANOVA analysis.

\begin{tabular}{cccccc}
\hline & Sum of Squares & $\mathrm{df}$ & Mean Square & $\mathrm{F}$ & Sig. \\
\hline Regression & 24.50 & 8 & 3.062 & 25.81 & 0.00 \\
Residual & 9.60 & 81 & 0.12 & & \\
Total & 34.10 & 89 & & & \\
\hline
\end{tabular}

Table 6. Coefficients.

\begin{tabular}{|c|c|c|c|c|c|}
\hline & \multicolumn{2}{|c|}{ Unstandardized Coefficients } & \multirow{2}{*}{$\begin{array}{c}\text { Standardized Coefficients } \\
\text { Beta }\end{array}$} & \multirow{2}{*}{$\mathrm{t}$} & \multirow{2}{*}{ Sig. } \\
\hline & B & Std. Error & & & \\
\hline CST & 2.65 & 0.37 & & 7.17 & 0.00 \\
\hline SR & -0.03 & 0.13 & -0.02 & -0.21 & 0.83 \\
\hline GRI & 0.03 & 0.05 & 0.05 & 0.52 & 0.60 \\
\hline FS & -0.37 & 0.09 & -0.36 & -4.19 & 0.00 \\
\hline ES & -0.17 & 0.104 & -0.13 & -1.61 & 0.11 \\
\hline EPS & 0.14 & 0.02 & 0.42 & 6.80 & 0.00 \\
\hline $\mathrm{L}$ & -0.12 & 0.02 & -0.51 & -6.16 & 0.00 \\
\hline GS & -0.002 & 0.004 & -0.04 & -0.63 & 0.53 \\
\hline $\mathrm{A}$ & 0.05 & 0.038 & 0.09 & 1.25 & 0.22 \\
\hline
\end{tabular}

Significant level at $5 \%$.

In addition, for every unit increase in firm size, a -0.372 unit decrease in Tobin's $\mathrm{Q}$ is predicted, holding all other variables constant. Furthermore, for every unit increase in environmental sensitivity, a 0.169 unit decrease in the Tobin's $Q$ is likely, holding all other variables constant. As SR is coded $(0=$ Otherwise, $1=$ Sensitive industry), for firms categorized as sensitive industry status, the predicted Tobin's $\mathrm{Q}$ would be 0.169 points lower than that for firms with a nonsensitive status. Moreover, the coefficient for EPS is 0.138 , implying that for every unit increase in EPS, a 0.138 unit increase in Tobin's $Q$ is predicted, holding all other variables constant. For every unit increase in leverage, a 0.124 unit decrease in the Tobin's $\mathrm{Q}$ is predicted, holding all other variables constant. For each unit increase in governance score would result in a 0.002 unit decrease in the Tobin's Q, holding all other variables constant. Finally, the coefficient for the size of the audit committee is 0.048 . Consequently, for each unit increase in the audit committee size, a 0.048 unit increase in Tobin's $Q$ is predicted, holding all other variables constant.

\subsection{2. $P$-Value Analysis}

The associated 2-tailed $p$-values are used in assessing whether a given coefficient is significantly different from zero. Considering an alpha ( $\alpha$ ) of 0.05 , the coefficients for SR $=0.027$ and GRI $=0.029$ are not significantly different from zero because their $P$-values-0.833 and 0.599 , respectively-are larger than $\alpha=0.05$. In contrast, the coefficient for firm size $=0.372$ is statistically significantly dif- 
ferent from zero because its $p$-value is less than $\alpha=0.05$. Nonetheless, the coefficient for ES $=0.169$ and the size of the audit committee $=0.048$ is not statistically significant because their $P$-values 0.111 and 0.215 , respectively, are greater than $\alpha=0.05$. Similarly, the coefficient for GS $=0.002$ is not significantly different from zero because the $P$-value $=0.530$ is larger than $\alpha=0.05$. Finally, the coefficients for EPS $=0.138$ and leverage $=0.124$ are statistically significantly different from zero because their $P$-values 0.000 are less than $\alpha=0.05$.

\subsection{3. $t$-Value Analysis}

The 2-tailed $t$-value $=1.96$, based on a $5 \%$ level of significance. The null hypothesis is rejected if the $t$-value is greater than 1.96 or less than -1.96 . Therefore, the null hypothesis is accepted for SR status, GRI, environmental sensitivity (ES), governance score and audit committee size, which confirms that there is no significant relationship. The null hypothesis is rejected for the firm-specific factors such as firm size, EPS and leverage and provides that these factors affect the score of Tobin's Q.

\subsection{Multicollinearity Analysis}

Table 7 reveals the multicollinearity on standardized and non-standardized coefficients that yield collinearity statistics with variance inflation factor (VIF) and tolerance level. In particular, multicollinearity is distinguished by VIF, which is the reciprocal of tolerance. According to Hair et al. (1995), when the VIF value is $>4$ or tolerance $<0.2$, it implies that there is a problem of multicollinearity. Based on the VIF values in Table 7, the data used in the model and regression analysis have no multicollinearity symptoms between the variables.

\section{Discussion}

The study results found that Tobin's $Q$ is statistically significantly impacted by leverage, EPS and firm size. The findings indicate a positive correlation between

Table 7. Multicollinearity analysis.

\begin{tabular}{|c|c|c|c|c|c|c|c|}
\hline \multirow[t]{2}{*}{ Model } & \multicolumn{2}{|c|}{$\begin{array}{c}\text { Unstandardized } \\
\text { Coefficients }\end{array}$} & \multirow{2}{*}{$\begin{array}{c}\begin{array}{c}\text { Standardized } \\
\text { Coefficients }\end{array} \\
\text { Beta }\end{array}$} & \multirow[t]{2}{*}{$\mathrm{t}$} & \multirow[t]{2}{*}{ Sig. } & \multicolumn{2}{|c|}{ Collinearity Statistics } \\
\hline & B & Std. Error & & & & Tolerance & VIF \\
\hline CST & 2.649 & 0.370 & & 7.168 & 0.000 & & \\
\hline SR & -0.027 & 0.126 & -0.019 & -0.211 & 0.833 & 0.411 & 2.433 \\
\hline GRI & 0.029 & 0.055 & 0.052 & 0.527 & 0.599 & 0.345 & 2.897 \\
\hline FS & -0.372 & 0.089 & -0.359 & -4.196 & 0.000 & 0.462 & 2.164 \\
\hline ES & -0.169 & 0.104 & -0.125 & -1.613 & 0.111 & 0.560 & 1.787 \\
\hline EPS & 0.138 & 0.020 & 0.424 & 6.804 & 0.000 & 0.871 & 1.148 \\
\hline $\mathrm{L}$ & -0.124 & 0.020 & -0.513 & -6.165 & 0.000 & 0.489 & 2.044 \\
\hline GS & -0.002 & 0.004 & -0.041 & -0.631 & 0.530 & 0.788 & 1.269 \\
\hline A & 0.048 & 0.038 & 0.086 & 1.250 & 0.215 & 0.709 & 1.410 \\
\hline
\end{tabular}


Tobin's Q and the considered independent variables, including GRI reporting, ES and SR status. However, the results found no association between the SR practices of the listed firms in Tadawul and the corporate financial performance. This implies that the firm's share prices or earnings are of non-value relevance to the financial performance of an entity. The findings are consistent with the results of Cormier and Magnan (2007) and Schadewitz and Niskala (2010), which found a negative relationship between share price and SR or CSR disclosure. In other words, shareholders do not find sustainability reports to be a value add to the firm's financial performance. As explained by Cardamone et al. (2012) and Carnevale et al. (2012), the perceived negative correlation can be attributed to the fact that SR is an expensive activity that requires an organization to divert resources from the most lucrative purposes. A similar negative correlation was established by Hassel et al. (2005) and Murray et al. (2006), indicating a negative link between SR practices and the firm's market value. However, none of these studies focused on establishing the relationship between Tobin's $Q$ score and the firm's characteristics, such as firm size, leverage and EPS.

In addition, the study outcomes indicate that SR, size of audit committee, governance score and GRI reporting practices have no statistically significant effect on the Tobin's $Q$ value. This implies that the sustainability reports that comply with GRI standard do not have relevant value. The outcomes contradict the empirical findings by Ansari et al. (2015), Ching et al. (2017), Dobre et al. (2015) and Traunt et al. (2017), which demonstrate that the SR, in compliance with GRI standards and assurance thresholds, tends to have a positive long-term impact on the overall firm's value, an integral component of the Tobin's Q score. However, the findings are consistent with the empirical outcomes of studies by Mulkhan (2013), Loh et al. (2017) and Lourenço et al. (2014), which state that use of GRI standards or quality assurance does not necessarily yield value relevance on the firm or its financial performance.

As observed by Shah, Arjoon and Rambocas (2016) and Wang (2015) in their studies carried out in developed economies, they demonstrated mixed evidence on the impacts of SR practices on financial performance, which in turn positively implicates Tobin's Q score. Studies by Bhatia and Tuli (2018), de Klerk and de Villiers (2012), Laskar and Maji (2018), Murray et al. (2006), Needles et al. (2016) and Wang (2015) found that SR practices by firms in developed economies have a positively impact on the financial performance, resulting in higher firm's value and earnings. Therefore, quality SR practices have an impact on the financial performance of a firm and inevitably yields improved Tobin's $Q$ value.

However, when studying individual factors that affect Tobin's $Q$ value, such as BVPS, share prices and EPS, several studies (Cardamone et al., 2012; Carnevale et al., 2012; Cormier \& Magnan, 2007; Schadewitz \& Niskala, 2010) have demonstrated a positive association between SR practices and the individual factors. Finally, the study extends the theoretical findings on SR practices and value relevance by providing empirical evidence on the effects on SR practices on finan- 
cial performance. Although the findings add to the existing mixed evidence from previous studies, the study specifically demonstrates the impacts of GRI standards, SR assurance and firm's characteristics on the firm's value using the Tobin's Q model.

\section{Conclusion}

The present study focuses on examining the value relevance of SR on financial performance among the listed firms in Tadawul by ascertaining whether Tobin's $\mathrm{Q}$ is statistically significant by specific firm's attributes, including firm size, leverage and EPS. The study outcomes show that Tobin's $Q$ is statistically significantly influenced by leverage, EPS and firm size. The study outcomes are supported by the empirical evidence presented by Novy-Marx (2012), which affirms that the value of Tobin's $Q$ is significantly affected by the firm's characteristics. Furthermore, the study confirms that no correlation exists between the SR practices of the listed firms in Tadawul and the corporate financial performance. Nonetheless, the outcomes refer to some mixed evidence on SR practices and value relevance of listed firms in terms of firm's characteristics.

In particular, the study affirms the contradicting findings by de Klerk and de Villiers (2012), Cormier and Magnan (2007) and Omran and El-Galfy (2014), by which the firm's characteristics appear to have value relevance on the financial performance as well as zero impact or no effect on the same. The effect on Tobin's Q is affirmed by the findings by Cardamone et al. (2012), Carnevale et al. (2012), Cormier and Magnan (2007), de Klerk \& de Villiers (2012), Loh et al. (2017), Murray et al. (2006) and Schadewitz and Niskala (2010). This indicates that SR practices of listed firms tend to have a positive influence on value relevance of diverse market performance indicators, including book value, earnings, market value, firm's returns, firm's market value and share prices. It is observed that all the aforementioned firm's characteristics have an effect on the Tobin's Q.

However, other studies, such as Moneva and Cuellar (2009) and Wang (2015), demonstrate a positive correlation between SR practices of listed firms and factors that affect Tobin's Q, including EPS, share prices, leverage and market values. Other findings indicate that SR practices do not influence a firm's financial performance (Coram et al., 2009; Hassel et al., 2005), whereas studies by Loh et al. (2017) and Lourenço et al. (2014) established that mandatory disclosure results in a positive correlation between SR or CSR disclosure and market value. In general, the major implication of the outcomes of the current study are that Tobin's $Q$ is statistically significantly affected by leverage, EPS and firm size and that SR practices can only improve the usefulness of the reported financial information.

\section{Future Studies and Limitations}

This study suffers from diverse limitations, such as the use of a relatively small sample of listed firms. Despite selecting 519 firms, only 25 firms that practice SR 
disclosure are the most relevant. However, the limited sample is attributed to the low number of participants voluntarily adopting SR and exclusively adopting GRI standards. Another limitation relates to the fact that only the GRI standards of reporting is tested without considering other frameworks such as IRI. Therefore, it is rather difficult to generalize the outcomes for sustainability reports generated using different reporting frameworks. The third limitation relates to the fact that the reliability and quality of the SR is confirmed using third-party assurance and GRI reporting framework alone without considering applicationlevel criterion.

Therefore, future studies should focus on using higher number of observations sample by enlisting more listed firms engaged in SR practices and possibly conducting a comparative analysis between Saudi Arabia and other GCC countries for instance Oman. Future studies should explore the association between the effects of Tobin's $Q$ on financial performance and SR practices using data from other developing economies of Islamic world. Suggestively, future studies should explore the value relevance of SR using other reporting frameworks, including IRI, in order to enhance the validity of the results that are generalized to the Islamic world as part of the developing economies. The studies should empirically confirm whether different SR frameworks yield the same value relevance to listed firms. Finally, future research should adopt comprehensive content analysis criteria for qualifying reliability and quality of sustainability reports in order to explore the institutional, social and cultural factors that affect the current and future sustainability reporting prospects in the GCC countries.

\section{Conflicts of Interest}

The authors declare no conflicts of interest regarding the publication of this paper.

\section{References}

Anandarajan, A., FrancisIftekhar, B., Hasan, I., \& John, K. (2011). Value Relevance of Banks: Global Evidence. Review of Quantitative Finance and Accounting, 36, 33-55. https://doi.org/10.1007/s11156-010-0170-7

Ansari, N., Cajias, M., \& Bienert, S. (2015). The Value Contribution of Sustainability Reporting-An Empirical Evidence for Real Estate Companies. ACRN Oxford Journal of Finance and Risk Perspectives, 4, 190-205.

Bebbington, J. (2001). Sustainable Development: A Review of the International Development, Business and Accounting Literature. Accounting Forum, 25, 128-157.

Belal, A. R. (2003). The Prospects for Corporate Social Reporting (CSR) in Bangladesh. Doctoral Dissertation, Sheffield: University of Sheffield.

Bhatia, A., \& Tuli, S. (2018). Sustainability Reporting: An Empirical Evaluation of Emerging and Developed Economies. Journal of Global Responsibility, 9, 207-234.

https://doi.org/10.1108/JGR-01-2018-0003

Bluman, A. (2018). Elementary Statistics. New York, NY: McGraw-Hill Education.

Boesso, G., \& Kumar, K. (2007). Drivers of Corporate Voluntary Disclosure: A Framework 
and Empirical Evidence from Italy and the United States. Accounting, Auditing and Accountability Journal, 20, 269-296. https://doi.org/10.1108/09513570710741028

Branco, M., \& Rodrigues, L. (2008). Factors Influencing Social Responsibility Disclosure by Portuguese Companies. Journal of Business Ethics, 83, 685-701.

https://doi.org/10.1007/s10551-007-9658-Z

Cardamone, P., Carnevale, C., \& Giunta, F. (2012). The Value Relevance of Social Reporting: Evidence from Listed Italian Companies. Journal of Applied Accounting Research, 13, 255-269. https://doi.org/10.1108/09675421211281326

Carnevale, C., Mazzuca, M., \& Venturini, S. (2012). Corporate Social Reporting in European Banks: The Effects on a Firm's Market Value. Corporate Social Responsibility and Environmental Management, 19, 159-177. https://doi.org/10.1002/csr.262

Carroll, A. B., \& Shabana, K. M. (2010). The Business Case for Corporate Social Responsibility: A Review of Concepts, Research and Practice. International Journal of Management Reviews, 12, 85-105. https://doi.org/10.1111/j.1468-2370.2009.00275.x

Casey, R. J., \& Grenier, J. H. (2015). Understanding and Contributing to the Enigma of Corporate Social Responsibility (CSR) Assurance in the United States. Auditing: A Journal of Practice and Theory, 34, 97-130. https://doi.org/10.2308/ajpt-50736

Ching, Y. H., Gerab, F., \& Toste, T. H. (2017). The Quality of Sustainability Reports and Corporate Financial Performance: Evidence from Brazilian Listed Companies. SAGE Open, 7, 1-9. https://doi.org/10.1177/2158244017712027

Choi, J. J., \& Dow, S. (2008). Institutional Approach to Global Corporate Governance: Business Systems and Beyond. London, UK: Emerald Group Publishing. https://doi.org/10.1016/S1569-3767(2008)9

Chwistecka-Dudek, H. (2016). Corporate Social Responsibility: Supporters vs. Opponents of the Concept. Forum Scientiae Oeconomia, 4, 171-180.

Cooper, S., \& Owen, D. (2007). Corporate Social Reporting and Stakeholder Accountability: The Missing Link. Accounting, Organizations and Society, 32, 649-667.

https://doi.org/10.1016/j.aos.2007.02.001

Coram, P. J., Monroe, G. S., \& Woodliff, D. R. (2009). The Value of Assurance on Voluntary Nonfinancial Disclosure: An Experimental Evaluation. Auditing: A Journal of Practice \& Theory, 28, 137-151. https://doi.org/10.2308/aud.2009.28.1.137

Cormier, D., \& Magnan, M. (2007). The Revisited Contribution of Environmental Reporting to Investors' Valuation of a Firm's Earnings: An International Perspective. Ecological Economics, 62, 613-626. https://doi.org/10.1016/j.ecolecon.2006.07.030

de Klerk, M., \& de Villiers, C. (2012). The Value Relevance of Corporate Responsibility Reporting: South African Evidence. Meditari Accountancy Research, 20, 21-38. https://doi.org/10.1108/10222521211234200

Deegan, C. (2000). Financial Accounting Theory. New York, NY: McGraw-Hill Book Company.

Deegan, C. M. (2002). The Legitimising Effect of Social and Environmental DisclosuresA Theoretical Foundation. Accounting, Auditing \& Accountability Journal, 15, 282-311. https://doi.org/10.1108/09513570210435852

Deegan, C. M. (2009). Financial Accounting Theory. Sydney, Australia: McGraw-Hill.

Dixon-Fowler, H. R., Slater, D. J., Johnson, J. L., Ellstand, A. E., \& Romi, A. M. (2013). Beyond "Does It Pay to Be Green?" A Meta-Analysis of Moderators of the CEP-CFP Relationship. Journal of Business Ethics, 122, 353-366.

https://doi.org/10.1007/s10551-012-1268-8 
Dobre, E., Stanila, G. O., \& Brad, L. (2015). The Influence of Environmental and Social Performance on Financial Performance: Evidence from Romania's Listed Entities. Sustainability, 7, 2513-2553. https://doi.org/10.3390/su7032513

Donaldson, T., \& Preston, L. E. (1995). The Stakeholder Theory of the Corporation: Concepts, Evidence and Implications. Academy of Management Review, 20, 65-91. https://doi.org/10.5465/amr.1995.9503271992

Dowling, J., \& Pfeffer, J. (1975). Organizational Legitimacy: Social Values and Organizational Behavior. Pacific Sociological Review, 18, 122-136. https://doi.org/10.2307/1388226

Dyllick, T., \& Hockerts, K. (2002). Beyond the Business Case for Corporate Sustainability. Business Strategy and the Environment, 11, 130-141. https://doi.org/10.1002/bse.323

Farneti, F., \& Guthrie, J. (2009). Sustainability Reporting by Australian Public Sector Organisations: Why They Report. Accounting Forum, 33, 89-98. http://isiarticles.com/bundles/Article/pre/pdf/32.pdf https://doi.org/10.1016/j.accfor.2009.04.002

Freeman, R. (1984). Strategic Management: A Stakeholder Approach. Boston, MA: Pitman.

Garg, P. (2015). Impact of Sustainability Reporting on Firm Performance of Companies in India. International Journal of Marketing and Business Communication, 4. https://doi.org/10.21863/ijmbc/2015.4.3.018

Golob, U., \& Bartlett, J. (2007). Communicating about Corporate Social Responsibility: A Comparative Study of CSR Reporting in Australia and Slovenia. Public Relations Review, 33, 1-9. https://doi.org/10.1016/j.pubrev.2006.11.001

Graham, C. R., \& King, R. D. (2000). Accounting Practices and the Market Valuation of Accounting Numbers: Evidence from Indonesia, Korea, Malaysia, the Philippines, Taiwan, and Thailand. The International Journal of Accounting, 35, 445-470. https://doi.org/10.1016/S0020-7063(00)00075-3

Gray, R., \& Milne, M. (2002). Sustainability Reporting: Who's Kidding Whom? Chartered Accountants Journal of New Zealand, 81, 66-70.

Gray, R., Adams, C., \& Owen, D. (2014). Accountability, Social Responsibility and Sustainability: Accounting for Society and the Environment. Upper Saddle River, NJ: Pearson Higher Education.

Gray, R., Kouhy, R., \& Lavers, S. (1995). Corporate Social and Environmental Reporting: A Review of the Literature and a Longitudinal Study of UK Disclosure. Accounting, Auditing and Accountability Journal, 8, 47-77. https://doi.org/10.1108/09513579510146996

Gray, R., Owen, D., \& Adams, C. (1996). Accounting \& Accountability: Changes and Challenges in Corporate Social and Environmental Reporting. Prentice Hall.

Hahn, R., \& Kühnen, M. (2013). Determinants of Sustainability Reporting: A Review of Results, Trends, Theory, and Opportunities in an Expanding Field of Research. Journal of Cleaner Production, 59, 5-21. https://doi.org/10.1016/j.jclepro.2013.07.005

Hair, J. F. Black, W. C., Babin, B. J., \& Anderson, R. E. (1995). Multivariate Data Analysis. New York, NY: Macmillan.

Hassanein, A., \& Hussainey, K., (2015). Is Forward-Looking Financial Disclosure Really Informative? Evidence from UK Narrative Statements. International Review of Financial Analysis, 41, 52-61. https://doi.org/10.1016/j.irfa.2015.05.025

Hassel, L., Nilsson, H., \& Nyquist, S. (2005). The Value Relevance of Environmental Performance. European Accounting Review, 14, 41-61. 
https://doi.org/10.1080/0963818042000279722

Hedberg, C. J., \& Malmborg, F. V. (2003). The Global Reporting Initiative and Corporate Sustainability Reporting in Swedish Companies. Corporate Social Responsibility and Environmental Management, 10, 153-164. https://doi.org/10.1002/csr.38

Hooghiemstra, R. (2000). Corporate Communication and Impression Management: New Perspectives Why Companies Engage in Corporate Social Reporting. Journal of Business Ethics, 27, 55-68. https://doi.org/10.1023/A:1006400707757

Hyršlová, J., Becková, H., \& Kubáňková, M. (2015). Sustainability Accounting: Brief History and Perspectives. The 9th International Days of Statistics and Economics, Prague, 10-12 September 2015.

Isaksson, R., \& Steimle, U. (2009). What Does GRI-Reporting Tell Us about Corporate Sustainability? The TQM Journal, 21, 168-181. https://doi.org/10.1108/17542730910938155

Junior, R. M., Cotter, J., \& Best, P. J. (2014). Sustainability Reporting and Assurance: A Historical Analysis on a World-Wide Phenomenon. Journal of Business Ethics, 120, 1-11. https://doi.org/10.1007/s10551-013-1637-y

Klassen, R., \& McLaughlin, C. (1996). The Impact of Environmental Management on Firm Performance. Management Science, 42, 1199-1214. https://doi.org/10.1287/mnsc.42.8.1199

Kolk, A. (2004). A Decade of Sustainability Reporting: Developments and Significance. International Journal of Environment and Sustainable Development, 3, 51-64. https://doi.org/10.1504/IJESD.2004.004688

KPMG (2008). International Survey of Corporate Responsibility Reporting in 2008. London, UK: KPMG.

KPMG (2013). International Survey of Corporate Responsibility Reporting in 2013. New York, NY: PMG International.

Laskar, N., \& Maji, S. P. (2018). Disclosure of Corporate Sustainability Performance and Firm Performance in Asia. Asian Review of Accounting, 26, 414-443. https://doi.org/10.1108/ARA-02-2017-0029

Lehmann, E. (1993). The Fisher, Neyman-Pearson Theories of Testing Hypotheses: One Theory or Two? Journal of the American Statistical Association, 88, 1242-1249. https://doi.org/10.1080/01621459.1993.10476404

Lin, C. S., Chang, R. Y., \& Dang, V. T. (2015). An Integrated Model to Explain How Corporate Social Responsibility Affects Corporate Financial Performance. Sustainability, 7, 8292-8311. https://doi.org/10.3390/su7078292

Lober, D. (1996). Evaluating the Environmental Performance of Corporations. The Journal of Managerial Issues, 8, 184-205.

Loh, L., Thomas, T., \& Wang, Y. (2017). Sustainability Reporting and Firm Value: Evidence from Singapore-Listed Companies. Sustainability, 9, 2112-2037. https://doi.org/10.3390/su9112112

Lourenço, C. I., Callen, J. L., Branco, M. C., \& Curto, J. D. (2014). The Value Relevance of Reputation for Sustainability Leadership. Journal of Business Ethics, 119, 17-28. https://doi.org/10.1007/s10551-012-1617-7

Magee, L. (1990). R2 Measures Based on Wald and Likelihood Ratio Joint Significance Tests. The American Statistician, 44, 250-253. https://doi.org/10.1080/00031305.1990.10475731

Mainardes, E., Alves, H., \& Raposo, M. (2011). Stakeholder Theory: Issues to Resolve. 
Management Decision, 49, 226-252. https://doi.org/10.1108/00251741111109133

Mashat, A. A. (2005). Corporate Social Responsibility Disclosure and Accountability: The case of Libya. Doctoral Dissertation, Manchester: Manchester Metropolitan University.

Mitchell, R. K., Agle, B. R., \& Wood, D. (1997). Toward a Theory of Stakeholder Identification and Salience. Academy of Management Review, 22, 853-886. https://doi.org/10.5465/amr.1997.9711022105

Mobus, J. (2005). Mandatory Environmental Disclosures in a Legitimacy Theory Context. Accounting, Auditing \& Accountability Journal, 18, 492-517. https://doi.org/10.1108/09513570510609333

Mohan, N., \& John, F. (2011). Value Relevance of Accounting Information-An Indian Perspective. Journal of Finance, Accounting and Management, 2, 16-26.

Moneva, J. M., Archel, P., \& Correa, C. (2006). GRI and the Camouflaging of Corporate Unsustainability. Accounting Forum, 30, 121-137. https://doi.org/10.1016/j.accfor.2006.02.001

Moneva, J. M., \& Cuellar, B. (2009). The Value Relevance of Financial and Non-Financial Environmental Reporting. Environmental Resource Economics, 44, 441-456. https://doi.org/10.1007/s10640-009-9294-4

Mouselli, S., \& Hussainey, K. (2014). Corporate Governance, Analyst Following and Firm Value. Corporate Governance, 14, 453-466. https://doi.org/10.1108/CG-03-2011-0093

Mowen, M. M., Hansen, D. R., \& Heitger, D. L. (2015). Cornerstones of Managerial Accounting (6th ed.). Boston, MA: Cengage Learning.

Mulkhan, U. (2013). Corporate Sustainability Reporting: A Content Analysis of CSR Reporting in Indonesia. Jurnal Perspektif Bisnis, 1, 73-89.

Murray, A., Sinclair, D., Power, D., \& Gray, R. (2006). Do Financial Markets Care about Social and Environmental Disclosure? Further Evidence and Exploration from the UK. Accounting, Auditing \& Accountability Journal, 19, 228-255. https://doi.org/10.1108/09513570610656105

Needles, B., Frigo, M. L., Powers, M., \& Shigaev, A. (2016), Integrated Reporting and Sustainability Reporting: An Exploratory Study of High Performance Companies. In M. Epstein, F. Verbeeten, \& K. Widener (Eds.), Performance Measurement and Management Control: Contemporary Issues (pp. 41-81). Bingley: Emerald Group Publishing Limited. https://doi.org/10.1108/S1479-351220160000031019

Nelson, S. P., \& Devi, S. (2013). Audit Committee Experts and Earnings Quality. Corporate Governance: The International Journal of Business in Society, 13, 335-351. https://doi.org/10.1108/CG-02-2011-0009

Novy-Marx, R. (2012). The Other Side of Value: The Gross Profitability Premium. Journal of Financial Economics, 103, 429-453. https://doi.org/10.1016/j.jfineco.2011.05.003

O’Donovan, G. (2002). Environmental Disclosures in the Annual Report: Extending the Applicability and Predictive Power of Legitimacy Theory. Accounting, Auditing \& Accountability Journal, 15, 344-371. https://doi.org/10.1108/09513570210435870

Ohlson, J. (1995). Earnings, Book Values, and Dividends in Equity Valuation. Contemporary Accounting Research, 11, 661-686. https://doi.org/10.1111/j.1911-3846.1995.tb00461.x

Oláh, J., Karmazin, G., Farkasné Fekete, M., \& Popp, J. (2017). An Examination of Trust as a Strategical Factor of Success in Logistical Firms. Business: Theory and Practice, 18, 171-177. https://doi.org/10.3846/btp.2017.018

Omran, M. A., \& El-Galfy, A. M. (2014). Theoretical Perspectives on Corporate Disclosure: 
A Critical Evaluation and Literature Survey. Asian Review of Accounting, 22, 257-286. https://doi.org/10.1108/ARA-01-2014-0013

Osarto, R. J., García, A., Mendes-Da-Silva, W., Simonetti, R., \& Monzoni, M. (2015). Sustainability Indexes: Why Join In? A Study of the "Corporate Sustainability Index (ISE)" in Brazil. Journal of Cleaner Production, 96, 161-170. https://doi.org/10.1016/j.jclepro.2014.10.071

Owen, D. (2007). Chronicles of Wasted Time? A Personal Reflection on the Current State of, and Future Prospects for, Social and Environmental Accounting Research. Accounting, Auditing \& Accountability Journal, 21, 240-267. https://doi.org/10.1108/09513570810854428

Phillips, R. (2003). Stakeholder Theory and Organizational Ethics. San Francisco, CA: Berrett-Koehler Publishers.

Przychodzen, J., \& Przychodzen, W. (2013). Corporate Sustainability and Shareholder Wealth. Journal of Environmental Planning and Management, 56, 474-493. https://doi.org/10.1080/09640568.2012.685927

Said, R., Sidek, N. Z., Azhar, Z., \& Kamarudin, K. A. (2017). State-of-the-Art Theories and Empirical Evidence: Selected Papers from the 6th International Conference on Governance, Fraud, Ethics, and Social Responsibility. London, UK: Springer. https://doi.org/10.1007/978-981-10-6926-0

Schadewitz, H., \& Niskala, M. (2010). Communication via Responsibility Reporting and Its Effect on Firm Value in Finland. Corporate Social Responsibility and Environmental Management, 17, 96-106. https://doi.org/10.1002/csr.234

Shah, K., Arjoon, S., \& Rambocas, M. (2016). Aligning Corporate Social Responsibility with Green Economy Development Pathways in Developing Countries. Sustainable Development, 24, 237-253. https://doi.org/10.1002/sd.1625

Sherman, R. W. (2009). The Global Reporting Initiative: What Value Is Added? International Business \& Economics Research Journal, 8, 9-22. https://doi.org/10.19030/iber.v8i5.3132

Simmons, J. M., Crittenden, V. L., \& Schlegelmilch, B. B. (2018). The Global Reporting Initiative: Do Application Levels Matter? Social Responsibility Journal, 14, 527-541. https://doi.org/10.1108/SRJ-12-2016-0218

Simnet, R., Vanstraelen, A., \& Chua, W. F. (2009). Assurance on Sustainability Reports: An International Comparison. Accounting Review, 84, 937-967. https://doi.org/10.2308/accr.2009.84.3.937

Smith, J., Haniffa, R., \& Fairbrass, J. (2011). A Conceptual Framework for Investigating "Capture" in Corporate Sustainability Reporting Assurance. Journal of Business Ethics, 99, 425-439. https://doi.org/10.1007/s10551-010-0661-4

Suchman, M. C. (1995). Managing Legitimacy: Strategic and Institutional Approaches. The Academy of Management Review, 20, 571-610. https://doi.org/10.5465/amr.1995.9508080331

Sun, N., Salama, A., Hussainey, K., \& Habbash, M., (2010). Corporate Environmental Disclosure, Corporate Governance and Earnings Management. Managerial Auditing Journal, 25, 679-700. https://doi.org/10.1108/02686901011061351

Surroca, J., Tribó, J. A., \& Waddock, S. (2010). Corporate Responsibility and Financial Performance: The Role of Intangible Resources. Strategic Management Journal, 31, 463490. https://doi.org/10.1002/smj.820

Truant, E., Corazza, L., \& Scagnelli, S. D. (2017). Sustainability and Risk Disclosure: An Exploratory Study on Sustainability Reports. Sustainability, 9, 636-656. 
https://doi.org/10.3390/su9040636

Tvaronavičienė, M., Shishkin, A., Lukáč, P., Illiashenko, N., \& Zapototskyi, S. (2017). Sustainable Economic Growth and Development of Educational Systems. Journal of International Studies, 10, 285-292. https://doi.org/10.14254/2071-8330.2017/10-3/21

Wang, M. C. (2015). Value Relevance of Tobin's Q and Corporate Governance for the Taiwanese Tourism Industry. Journal of Business Ethics, 130, 223-230.

https://doi.org/10.1007/s10551-014-2339-9

Yammeesri, J., \& Herath, S. K. (2010). Board Characteristics and Corporate Value: Evidence from Thailand. Corporate Governance: The International Journal of Business in Society, 10, 279-292. https://doi.org/10.1108/14720701011051910 